\title{
Ethnic Conflict in Pakistan: The Case of MQM
}

\author{
MOHAMMAD WASEEM
}

\begin{abstract}
It has been argued that the current scholarship on ethnicity is focused on the rise of ethnonationalism, without incorporating the possibility and the nature of decline in its scope and intensity. An absolute majority of such movements have indeeded been contained in the postwar era. There is no reason to believe that this trend will reverse in near future. In this context, one can point to Pakistan, Baloch and Sindhi nationalist movements within Pakistan. Our discussion of the rise of the mohajir movement in this paper provides clear indicators of the potential determinants of its decline.

It is significant that it is the state at the non-policy level which created a situation of ethnic explosion in urban Sindh. Various macro-level explosive issues revolving around conflicts between politicians and army, federalist and provincial forces, Islamist and secularist elements and, externally, India and Pakistan seriously circumscribed the state's capacity and will to persue micro-level issues such as urban planning educational and manpower strategies, rural-urban and inter provincial migration and investment in mental infrastructure in general. The abdication of policy by the state rendered it inactive and irrelevent. This 'residual' state was represented by officials at the bottom level who controlled a vast number of transactional activities outside the purview of law.

Ethnicity emerged as the new source of definition and categorisation of interests and identity formation as the state defaulted on various counts such as citizen orientations, legal protection and security of life and property. In other words, it was not too much of the (Jacobin) state, as primordialists would have us believe, but rather too little of it which produced the mohajir ethnic consciousness. We can maintain that the process of nativisation of mohajir is the product of multiple locational and transactional activities which do not necessarily reflect state policies.
\end{abstract}

\section{INTRODUCTION}

A large number of countries in the contemporary world have experienced ethnic revival in recent times. Ethnolinguistic communities which lived within the framework of so-called nation-states have started asserting themselves in search of a separate political identity, devolution of power and even independence. Ethnonationalist movements have taken different forms ranging from holding of referendums for determining the issue of devolution or independence to resorting to armed struggles. The process of decolonisation left issues of delimiting proper frontiers between new states or determining the fate of migrant populations living outside their homelands unresolved. This led to irridentist claims of certain countries 
to parts of the territory of neighbouring states and to their support for ethnic movements.

Mohajir nationalism represents a paradox in the context of ethnic conflict. Unlike Bengali, Sindhi, Pakhtun and Baloch nationalist movements which represented relatively well-defined historical communities identified with their respective geographical units, the mohajir ethnicity is still passing through its birth pangs. In other words, the task of analysing the mohajir ethnic movement simultaneously involves the study of ethnicity-in-making. In this paper, we plan to focus on the way the mohajir community came to itself as an entity separate from the host society. Secondly, the clue to mohajir nationalism lies in the fact that this migrant community has launched a 'sons of the soil' movement of its own. We shall analyse this movement in terms of transformation of a migrant community into a self-conscious native community seeking to carve out a political space for itself.

The debate about ethnicity relates to a choice between the latent sources of ethnic identity and their manipulation by ethnonationalists as the determining variable. Many researchers have focused on primordial loyalties being at the heart of the ethnic revival of our times. These loyalties are either defined in terms of blood ties of tribe, family and kin or understood as social and cultural 'givens' such as custom, language, religion and descent. ${ }^{1}$ In this framework, the unique (common) origin, history, cultural individuality and a sense of collective solidarity emerge as the leading primordial features of an ethnic community. ${ }^{2}$ Primordialists have been generally criticised for focusing on historical and mythical symbols without fully bringing out the political uses of these symbols by 'ethnic entrepreneurs'. As opposed to primordialists, instrumentalists or circumstantialists consider ethnic ties to be socially and culturally constructed. ${ }^{3}$ For example, Brass argues that ethnicity is not a given; instead it is a social and political construction. Elites who are in competition for resources 'draw upon, distort and sometimes fabricate materials from the cultures of the groups' for collective and individual advantages. ${ }^{4}$ Secondly, the activities of the modern centralised state play a pivotal role in pushing the elites of the non-dominant groups to ethnic nationalism. ${ }^{5}$ The process of selection and manipulation of symbols in order to define ethnic boundaries serves the crucial function of identity formation as the basis for political mobilization. ${ }^{6}$ State policies and elite competition, then, emerge as central variables in Brass' theory of ethnic nationalism.

${ }^{1}$ Edward Shils, 'Primordial, Personal, Sacred and Civil Ties', British Journal of Sociology, Vol. 8,

No. 2, p. 142, and Clifford Geertz, The Interpretation of Cultures, 1973, p. 259.

${ }^{2}$ Anthony D. Smith, The Ethnic Revival, Cambridge, 1981, p. 10.

${ }^{3}$ J. D. Eller and R. M. Coughlan, 'The Poverty of Primordialism: The Demystification of Ethnic Attachments', Ethnic and Racial Studies, Vol.16, No. 2, April 1993, pp.194-97.

${ }^{4}$ Paul R. Brass, Ethnicity and Nationalism, Sage: New Delhi, 1991, p. 8.

${ }^{5}$ Ibid. pp. 8-9.

${ }^{6}$ Ibid. p. 101. 
Competition between ethnic groups can also take place when one of them happens to be migrant, either directly or by descent. Weiner has discussed ethnic movements in India against the perceived dominance of migrants from elsewhere in the country in terms of nativist sentiments. These movements tend to project territory as a source of legitimacy for demanding jobs for locals and constructing a culturally distinct identity. ${ }^{7}$ Rapid growth of education in the lower middle class among locals creates a demand for jobs which are already in the hands of the migrant middle class. That creates a nativist reaction couched in a middle class sentiment. ${ }^{8}$ When state governments make preferential policies in favour of locals, it serves the political purpose of gaining their support while the cost of alienating migrant minorities is considered politically bearable. ${ }^{9}$

Mohajirs migrated to Pakistan in 1947 from different geographical regions, linguistic groups and ethnic communities of India. As such, the primordialist position that ethnicity is a product of common history, language, territory and tradition does not explain the mohajir movement. As for the instrumentalist approach, it focuses on the activist dimensions of an ethnic movement including its organisational profile, strategy of mass mobilisation and political agenda. However, the two core variables of the instrumentalist approach, i.e., elite competition and state policies are problematic in this context. First, the MQM's movement is typically non-elite. Most of the MQM's party ideologues, campaign organisers, and militant activists belong to lower middle class. Secondly, the centrality of the state policies for explaining the mohajir phenomenon has to be considered with great caution, especially as some analysts have actually applied this model to previous ethnic movements in Pakistan. ${ }^{10}$ In a typical third world country, state's policies do not incorporate large sectors of public and private activity where patterns of interaction at the local level create new interpersonal, inter-sectoral and inter-ethnic conflicts. In the case of mohajir nationalism, a whole series of changes ranging from regional developments such as the Afghanistan war to indigenous revival in Punjab and Sindh defy an explanatory model based on state policies. ${ }^{11}$

\section{MAKING OF THE MOHAJIR COMMUNITY}

Mohajirs constitute a part of the population which migrated from India to Pakistan after partition in 1947. A majority of migrants came from East Punjab and

${ }^{7}$ Myron Weiner, Sons of the Soil: Migration and Ethnic Conflict in India, Princeton, 1978, pp. 24, 113-120, 180-81, 228-29, 237.

${ }^{8}$ Ibid. pp. 285-93.

${ }^{9}$ Myron Weiner and Mary F. Katzenstein, India's Preferential Policies: Migrants, the Middle Classes, and Ethnic Equality, Chicago, 1981, p. 130.

${ }^{10}$ See Tahir Amin, Ethnonational Movements of Pakistan, Islamabad, 1988, pp. 8-9.

${ }^{11}$ For application of Brass's state-centred model, see ibid. pp. 223, 254-55. 
settled in West Punjab. They got relatively assimilated with the native population within a generation. On the other hand, mohajirs came from areas further east, south and west in India and settled mainly in urban Sindh. They remained largely unassimilated with the local population even after two generations.

\begin{tabular}{lccc}
\multicolumn{4}{c}{ Patterns of Migration } \\
\hline 1. Pakistan & $\begin{array}{c}\text { Number of } \\
\text { Refugees }\end{array}$ & $\begin{array}{c}\text { Share of } \\
\text { Refugees }\end{array}$ & $\begin{array}{c}\text { Ratio in Total } \\
\text { Population }\end{array}$ \\
2. East Bengal & 7.22 million & 100 & $10 \%$ \\
3. W. Pakistan & .7 million & $9.67 \%$ & $1.7 \%$ \\
4. Punjab & 6.52 million & $90.3 \%$ & $20 \%$ \\
5. Sindh (ex K) & 5.3 million & $73 \%$ & $25.6 \%$ \\
6. Karachi & .55 million & $7.6 \%$ & $11.7 \%$ \\
\hline
\end{tabular}

Source: Census of Pakistan 1951, Vol. I, Table 19-A, Vol. 6, p. 65.

Unlike in Punjab, refugees in Sindh defied integration in the local society because of their linguistic, cultural and historical remoteness from Sindhis. These differences were patterned along sectoral lines. 63.9 percent of refugees in Sindh lived in urban areas, 86.16 percent in Hyderabad district and 71 percent in Sakhar. ${ }^{12}$ In Karachi, there were only 14.28 percent speakers of Sindhi in 1951 as opposed to 58.7 percent who spoke Urdu as their mother tongue. ${ }^{13}$ Thus, Karachi overnight became a mohajir city. The government of Pakistan carved the city out of Sindh in July 1948. It became a federally administered area as capital of Pakistan.

The process of refugee rehabilitation in Karachi and Sindh generally remained far from satisfactory. Even in 1954, i.e. 7 years after partition, no less than 2,40,000 out of a total of 7,50,000 refugees in Karachi were still to be rehabilitated. ${ }^{14}$ While in Punjab, immigration had virtually stopped in 1948, in Sindh it continued even after the passport and visa system was introduced for travel between India and Pakistan. About 1,00,000 refugees from India continued to come to Pakistan each year, with a majority belonging to 'urban classes' who generally came straight to Karachi. This created an immense problem of settlement, which in turn led to gross frustration among refugees.

\footnotetext{
${ }^{12}$ Census of Pakistan, Karachi, 1951, Vol. 6, Statement 3-R, p. 36.

${ }^{13}$ Ibid. Vol. 1, Statement 5-C, p. 87.

${ }^{14}$ Debates (CAP), 23 March 1954, p. 405.
} 
Mohajirs constitute a privileged community on the decline. Initially, they dominated the All India Muslim League in British India and later the government in Pakistan. ${ }^{15}$ However, they occupied an inherently insecure position in terms of electoral politics. Prime Minister-designate Liaqat Ali Khan who was a mohajir was inducted into the Constituent Assembly in place of an elected member from East Bengal. The mohajir leadership chose to bypass the Constituent Assembly which had been elected by the Muslim members of the legislative assemblies of Muslim majority provinces comprising Pakistan, and which was therefore dominated by 'locals.' It shunned elections which would lead to its exit from power. Instead, it operated through the higher bureaucracy which was also dominated by migrants of both Punjabi and mohajir extraction. Mohajirs who were only 3 percent of the population had 21 percent jobs. ${ }^{16}$ Among senior jobs, mohajirs had 33.5 percent in federal bureaucracy in 1973 and 20 percent in the Secretariat group in 1974; however, their share came down to 18.3 percent in 1986 and 14.3 percent in 1989 respectively. ${ }^{17}$

Mohajirs not only dominated politics and bureaucracy but also business. The Gujrati-speaking migrants from Bombay in India, especially Memon, Bohra and Khoja communities, were in the vanguard of industrialisation in Pakistan. Gujratispeaking mohajirs controlled seven of the twelve largest industrial houses. ${ }^{18}$ In 1972, when Bhutto nationalised industry in the ten leading sectors including electrical engineering, petrochemicals, iron and steel as well as rudimentary automotive assembly plants, mohajirs were dealt a severe blow.

The mohajir-led political leadership in the immediate postindependence period sought to identify Pakistan with the Islamic world. Political loyalties in Pakistan were thus 'externalised' in the name of religion. ${ }^{19}$ Mohajirs also continued to be deeply involved in the fate of Indian Muslims across the border. They were acutely sensitive to the latter's needs to get jobs and tried to help them migrate to Pakistan. Indeed, mohajirs interpreted the Two Nation Theory itself in the context of the right of Indian Muslims to migrate to Pakistan. This led to a general deification of the state, accompanied by a cult of unity of the nation in the face of the perceived Indian bellicosity, largely at the cost of provincial autonomy, indigenous cultures and

\footnotetext{
${ }^{15}$ Both the first Governor general and the first prime minister of Pakistan were mohajirs. Similarly, the Central Working Committee of the Muslim League was also dominated by mohajirs.

${ }^{16}$ For a detailed discussion, see Mohammad Waseem, Politics and the State in Pakistan, Islamabad, 1994, p. 109; also Table 4, p. 108.

${ }^{17}$ Charles H. Kennedy, 'Managing Ethnic Conflict: The Case of Pakistan', Regional Politics and Policy, Vol. 3, Spring 1993, No. 1, pp. 138-9.

${ }^{18}$ Hanna Papanek, 'Pakistan’s Big Businessmen', Economic Development and Cultural Change, 21, 1972, pp. 25.

${ }^{19}$ Hamza Alavi, 'Nationhood and Communal Violence in Pakistan', Journal of Contemporary Asia, Vol. 21, No. 2, 1991, p. 154.
} 
local languages. ${ }^{20}$ Mohajirs' political attitudes were typically based on a paternalistic vision of the society, enhanced commitment to ideological mobilisation and lack of tolerance for provincial and ethnic aspirations.

Three broad areas of change adversely affected mohajirs: first, One-Unit was conceived to counter the weight of Bengalis in the National Assembly of Pakistan in view of the latter's share of 55 percent in the country's population. However, under One Unit, it was Punjabis not mohajirs who expanded their job circuit. Secondly, the 1958 coup put Punjabi generals in control of key positions in the corporate sector, opening up jobs for their co-ethnics. Finally, the shift of capital to Islamabad in the vicinity of the General Headquarters in Rawalpindi pointed to the centrality of Punjab-based army in the new dispensation, largely at the expense of mohajirs.

Pakistan was a state infused with a dominant migrant ethos, couched in an ideological framework of the Two-Nation Theory as the raison d' etre of Pakistan. The ruling elite took pride in the achievements of the Indo-Muslim civilisation over a thousand years and appropriated its symbols such as Urdu language, Moghul architectural monuments and the Indo-Iranian tradition of art. The 1970 election was to change all that. The elite was unable to take into account the massive currents of indigenous revival in East Bengal, Punjab and Sindh. In (W) Pakistan, the Indus Valley overtook the Indo-Muslim civilisation as a source of cultural symbols. Territorial nationalism pushed aside ideological nationalism as the dominant mode of thinking. The popular refrain in the 1970s was that Pakistan was the home of four cultures, Sindhi, Punjabi, Baloch and Pakhtun. This gradually legitimised the thesis that Pakistan consisted of four nationalities. The new populism flourished at the cost of the cherished worldview of the migrant elite rooted in a unitarian model of politics. In 1970, the state of Pakistan which was originally conceived in nonPakistan areas finally took roots in the languages and cultures of the country itself.

The indigenous revival put a new generation of Sindhi leadership in power. It represented popular aspirations identified with historical and cultural identity of Sindh and was committed to the goal of cultural preservation against the perceived onslaught of mohajirs. It criticised the fact that only one fourth of the material in school text books reflected indigenous Pakistani cultures and their heroes while three fourths represented northern Indian cultural symbols and that making of Pakistan was attributed predominantly to Muslims of minority provinces while the role of majority provinces, especially Sindh which voted for Pakistan before others, was ignored. ${ }^{21}$

The land question was another major source of Sindhi nationalist sentiment. Out of the land brought under cultivation by Ghulam Mohammad, Guddu and Sakhar

\footnotetext{
${ }^{20}$ For a discussion of the migrant ethos, see Mohammad Waseem, op. cit., pp. 110-11.

${ }^{21}$ Aftab Kazi, 'Ethnic Nationalities, Education and Problems of National Integration in PakistanII’, Sindh Quarterly, 1989, No.1, pp. 21-27.
} 
Barrages, 1.48 million, 0.64 million and 0.28 million acres respectively, ex-military officers and bureaucrats among others-mostly Punjabi but also mohajirs-were allotted .87 million, 0.32 million and 0.13 million acres in that order. ${ }^{22}$ The standard mohajir response to Sindhis' protest was that Sindhi waderas were too much given to a life of luxury and Sindhi haris were far too condemned to a life of misery to cultivate lands irrigated by Sukhar Barrage and that mohajir domination in education and services was the product of inability or unwillingness of Sindhis to fill the vacuum created by the departing Hindus. ${ }^{23}$ Mohajirs favoured an open system of recruitment to educational institutions, jobs and businesses through competition on the basis of merit. Sindhis wanted protection through a fixed quota for jobs and services.

\section{NATIVISATION OF A MIGRANT COMMUNITY}

During the second quarter century after independence, mohajirs' social vision was effectively 'nativised'. They now looked at themselves as belonging to Sindh and, especially, Karachi. This happened due to arrival of new migrants who challenged their cultural, economic and political interests. During the last half century, Karachi experienced four major waves of migration, comprising mohajirs (1940s-50s), Punjabis and Pathans (1960s-80s), Sindhis (1970s-90s), and foreigners including Afghans, Iranians, Iraqis, Ethiopians, Sri Lankans, Bangladeshis, Burmese, Thais and Philipinos among others (1980s-90s).

The mohajir mass public which represented the bulk of the first wave migrants squatted in kachi abadis in conditions of acute residential and income insecurity. This situation reflected their helplessness with the local government for provision of tenure and civic amenities. ${ }^{24}$ During the 1980s, the popular idiom shifted away from the two traditional sources of mohajir identity formation, Islam and Pakistan. ${ }^{25}$

The second wave of migrants representing Punjabis and Pathans has been defined as 'circular migration' as opposed to the 'permanent migration' of mohajirs. The former kept relations with family back home and visited home at varying intervals. It was estimated that out of 350,000 new inhabitants of Karachi every year, 150,000 were migrants from upcountry. ${ }^{26}$ Punjabi migrants entered jobs in the new industrial units. They were followed by Pathan construction workers, diggers of soil,

${ }^{22}$ Abbas Rashid and Farida Shaheed, Pakistan: Ethno-Politics and Contending Elites. UNESCO Discussion Paper 45, 1993, p. 16.

${ }^{23} \mathrm{Jang}, 31$ October 1987.

${ }^{24}$ Peter Nientied, 'Usmania Mohajir Colony in 1973 and 1983', in Jan Van der Linden and Frits Selier (eds), Karachi: Migrants, Housing and Housing Policy. Vanguard, Lahore, 1991, p. 138.

${ }^{25}$ Feroz Ahmed, 'The Rise of Mohajir Separatism in Pakistan', Pakistan Progressive. Wisconsin Osh Kosh, Summer/Fall 1989, Vol. 10, No. 2/3, p. 39.

${ }^{26}$ Frits Selier, 'Family and Rural-Urban Migration in Pakistan', in Jan Van der Linden and Frits Selier (eds), op. cit., p. 5. 
retail sellers and transport workers. At least half of them behaved as working-life migrants tied with home. ${ }^{27}$ Unlike the first wave migrants, the second wave migrants tended to keep their upcountry identity and loyalty intact.

Linguistic Groups in Karachi

\begin{tabular}{lcccccc}
\hline Urdu & Punjabi & Pushto & Sindhi & Balochi & Hindko & Others \\
\hline $54.3 \%$ & $13.6 \%$ & $8.7 \%$ & $6.3 \%$ & $4.4 \%$ & $1 \%$ & $11.7 \%$ \\
\hline
\end{tabular}

Source: 1981 Census Report of Karachi Division. Islamabad, 1984, p. 10.

In Karachi, ethnicity emerged as the dominant theme in the 1980s as the mass of humanity living off the mainstream 'planned' social and political life developed its own rules of game for survival. Ethnic groups were huddled together into informal security structures woven around vested interests such as jobs, houses, security against eviction or bulldozing of illegal tenements and other psychological support mechanisms. Mohajirs started developing a sense of nationalism about Karachi and Sindh as a bulwark against Punjabi and Pathan migrants. Previously, Punjabis had joined hands with mohajirs and Pathans to form the Mohajir-PunjabiPakhtun Muttahida Mohaz which sought to safeguard the rights of the three migrant communities in Sindh. However, as mohajirs sought to co-operate with Sindhis against Punjabis, the latter reacted by closing their gap with Sindhis.

The third wave of migration brought Sindhis into Karachi and Hyderabad. Reintegration of Karachi with Sindh in an administrative and 'political' sense in 1970 and installation of a PPP government led by nationalist elements under Mumtaz Ali Bhutto as well as acts such as passing of the Language Bill and introduction of the quota system made the presence of Sindhis felt in the city. The quota system provided jobs for the nascent Sindhi middle class. Moreover, the late arrival of Green Revolution in Sindh in the 1980s displaced many Sindhi tenants and haris from land and pushed them to Karachi. ${ }^{28}$

The fourth wave of migration emerged in the 1980s when nationals of the neighbouring countries started coming to Karachi. A huge market in manpower transport emerged in the east of Arabian Sea extending to India, Sri Lanka, Bangladesh, Burma, Indonesia and Philippines up to South Korea. Karachi became an important mid-way stop on the route to the Gulf, often becoming the hub of underground activity surrounding traffic in workers, drug and women from Bangladesh and Philippines. The number of political refugees from Afghanistan, Iraq (Kurds), Iran (Bahais), Burma (Muslims), and Sri Lanka (Tamils) and economic

\footnotetext{
${ }^{27}$ Ibid. pp. $25-27$.

${ }^{28}$ S. Akbar Zaidi, 'Sindhi vs Mohajir in Pakistan: Contradiction, Conflict, Compromise', Economic and Political Weekly. May 16, 1991, p. 1297.
} 
refugees from Philippines, Bangladesh, Thailand, Somalia and Ethiopia in 1995 rose to $1,626,324{ }^{29}$

The first wave migrants-mohajirs-resent the second, third and fourth wave migrants, and now consider themselves 'natives' of Karachi and Sindh. They view Punjabis and Pathans as migrants of fortune who earn in Karachi but send back their earnings to their families upcountry, and invest money there in property and education of children, involving a net transfer of resources from Karachi. Mohajirs also object to the Sindhis' practices of earning in Karachi and spending in the interior.

\section{MQM: A POLITICAL PROFILE}

Squatter settlements provided a fertile ground for the ethnic message of mohajir student activists. Universities and colleges crystallised mohajir consciousness. Mohajir students had to contend with student associations organised on linguistic and regional lines, including the Punjab Students Association, Pakhtun Students Association, Baloch Students Organisation and Jiye Sindh Students Federation. This led to formation of the All Pakistan Mohajir Students Organisation (APMSO) in 1978. APMSO was a product of the perceived mohajir grievances in terms of non-delivery of promises of the PNA leaders to eliminate the quota system and to secure the lives of mohajirs against the perceived tyranny and violence. These student leaders later formed the MQM in 1984. In the new party, blind faith in the leader provided a string binding different participants of the movement. ${ }^{30}$ The MQM created a strong cult of personality of Altaf Hussain. ${ }^{31}$

The non-elite character of the MQM leadership gave it a certain level of legitimacy to call itself a party of the poor. It claimed that it had broken the spell of traditional drawing room politics of capitalists and feudals and brought the poor and middle class leadership into assemblies. ${ }^{32}$ It observed that masses could not vote according to their own choice because jagirdars, waderas, sardars and nawabs held them down under their cruel and dictatorial system. ${ }^{33}$ It vowed to establish a system in the country under which there would be the rule of not the 2 percent privileged but the 98 percent poor and middle class. ${ }^{34}$ However, despite its progressive rhetoric, the MQM lacked any policy structure, reform programme or legislative proposals in the

\footnotetext{
${ }^{29}$ Mohammad Suleman Sheikh, 'The Issue of Migration in Pakistan', Unpublished paper, Islamabad, 1995, p. 2.

${ }^{30}$ Imran Farooq, Imperatives of Discipline and Organisation, (Urdu), MQM document, Karachi, pp. 10-17.

${ }^{31}$ Reply Statement of the Government of Pakistan and the Government of Sindh in the Supreme Court of Pakistan, 5 June 1995, Petition No. 46/94, pp. 32-33.

${ }^{32}$ MQM is the Symbol of Being Oppressed, (Urdu), MQM document, Karachi, 1994, pp. 6, 13.

${ }^{33}$ Ibid. p. 14.

${ }^{34}$ The Rule of the Poor, (Urdu), MQM document, Karachi, n.d., p. 7.
} 
direction of alleviation of poverty. Not surprisingly, the MQM's self-image as a party of the poor lacked credibility in the eyes of non-mohajirs everywhere. In the public view, the MQM pitted the poor of one community against the poor of the other community across the street, not against the rich from the other side of the city. ${ }^{35}$ The MQM can be considered as a policy-neutral, ideologically agnostic and pro-status quo party despite claims to the contrary.

The quota system has been at the heart of the MQM politics. After the Sindhidominated PPP government took power in Karachi in 1971, the issue of the share of Sindhis in education and jobs re-emerged on the political agenda. The MQM points to a deliberate policy of discrimination against mohajirs. Similarly, the fate of a quarter of a million Biharis in Bangladesh is a constant reference in the MQM's literature. The party has strongly criticised the government of Pakistan for not accepting its own citizens back into the country. A closely related issue is population because it has implications for jobs and elections. The MQM has claimed that mohajirs constituted 60 percent of the population in Sindh and that the 1961, 1972 and 1981 census figures were manipulated to reduce the population of mohajirs by more than half. ${ }^{36}$

The MQM defined mohajirs as those who (i) migrated to Pakistan from Muslim minority provinces of the sub-continent at the time of the partition, (ii) are not considered to belong to any of the nationalities of Pakistan-neither Punjabi, nor Sindhi, nor Balochi, nor Pakhtun, and (iii) migrated from those areas of East Punjab whose language and culture was not Punjabi. ${ }^{37}$ The MQM took exception to the fact that the four provinces of Pakistan were constantly being declared as four brothers, excluding those who did not originally belong to any of these provinces. ${ }^{38}$ Altaf Hussain declared that the slogan of mohajir nationality was indeed the product of reaction to the slogan of four nationalities. ${ }^{39}$ It was claimed that mohajirs had now aligned themselves with the destiny of Sindh and become de facto sons of the soil. The MQM demanded rationalisation of the prevalent domicile system so that only those locals should be issued domicile who had lived in Sindh along with their whole family for at least 20 years. It defined 'locals' as those who lived a family life, earned, spent, died and got buried in, and linked their interests with, the interests of Sindh. ${ }^{40}$ This was essentially a nativistic idiom rooted in a part of the territory of Sindh.

The MQM leadership's hobnobbing with the Sindhi nationalist leadership reflected its political stand against the upcountry migrants. The latter formed a new

${ }^{35}$ Herald, Karachi, February 1988, p. 58.

${ }^{36}$ MQM: Constitutional Petition in the Supreme Court of Pakistan, Part 1, Boston, 1994, pp. 4-5.

${ }^{37}$ The Journey of Life (Autobiographical account of Altaf Hussain), Jang Publishers, Lahore, p. 103.

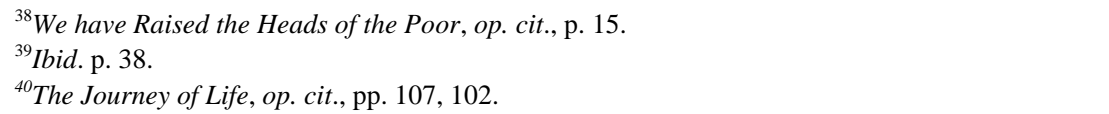


party, the Punjabi Pakhtun Ittehad (PPI) on 7 March 1987. However, the PPI never really took off. In the 1988 elections, MQM and PPP bagged almost all mohajir and Sindhi seats representing the two ethnic nationalisms respectively. The MQM and PPP formed a coalition and signed the Karachi Accord as a basis for co-operation. However, soon their distinct party profiles on the issue of implementation of the Accord led them apart. The downhill march of the coalition culminated in a secret alliance between the IJI opposition and MQM which was disclosed and signed on 24 October 1989 on the eve of the no-confidence motion against Benazir Bhutto. Violence increased on the street and so did army's involvement in civil administration.

\section{MQM: POLITICS OF CONFRONTATION}

The MQM's partnership in the IJI government from 1990-92 represented the high point in its street power whereby it sought to maintain an iron grip on all mohajir public activity. The press was a special target of the MQM workers who burnt thousands of copies of the daily Dawn and stopped its distribution, looted the offices of daily Jang, and attacked the houses of journalists. It demanded full coverage of its activities on prominent places on the papers, condemned critical views about the party and sought to punish those who would not oblige. As long as some sections of the mohajir population stayed outside its fold, the MQM felt that its legitimacy as an exclusively mohajir party remained less than total. These people were called traitors to the mohajir cause and were sometimes beaten, abducted and tortured to teach a lesson to others. Mohajirs were still far from integrated into a community because of their different linguistic, geographic and cultural backgrounds. In order to bind them together and put them immediately at the front of the political stage, unity by command rather than by persuasion was considered to be the way out. In 1989-90, the MQM played the local bully for a national level political alliance, with a larger political objective of destabilising the PPP government. Again in 1994-95, the MQM's strategy focused on destabilising the PPP government by exposing its inability to control street violence.

The MQM kept the momentum of its street politics high when it was a partner in Jam Sadiq Ali's government in Sindh. Its share in state power, combined with its unchallenged street power, produced an inordinately high level of confidence in the party workers. Moving beyond the rival ethnic groups and internal dissidents as targets of their action, the party workers abducted and tortured a serving army officer, Major Kaleem Ahmad. That was the last straw which brought the army into play with full force. On 19 June 1992, army started Operation-Clean up in Sindh. It claimed that it had got hold of maps of 'Jinnahpur' or 'Urdu Desh' meant to be carved out of Sindh including Karachi, Hyderabad and some coastal area as an independent country by the MQM. It also unearthed $22 \mathrm{MQM}$ torture cells, including 
one in Abbasi Shaheed Hospital. ${ }^{41}$ Many of the top leaders of the MQM including Altaf Hussain were declared proclaimed offenders. Many others, including MNAs and MPAs of the MQM went underground. The latter resigned from membership of the two assemblies. The army allegedly sponsored a rival faction within the MQM, called Haqiqi, comprising opponents of the Altaf group.

The MQM boycotted the 1993 elections for the National Assembly but it participated in the Sindh Assembly elections three days later and won 27 out of 100 seats. The new Benazir Bhutto government started a dialogue with the MQM, especially after the latter voted for the PPP nominee Farooq Leghari as president. However, each round of talks ended in failure. In June 1994, Altaf Hussain was sentenced by the Suppression of Terrorist Activities Court to a 27 year jail term. In a series of open letters addressed to armed services chiefs, Altaf Hussain accused the military unit FIT and 'officials of the armed forces' in general of perpetrating atrocities on mohajirs, extracting bribes from people worth millions of rupees and becoming 'wealthy but devoid of moral fibre and patriotism'. ${ }^{42}$ In December 1994, the civil armed forces took over from the regular army units in Sindh. In the aftermath of the army withdrawal, the MQM launched its major attack on the institutions of civil administration and sought to create a law and order situation out in the street. In July 1995, a new Operation Clean-up was started in Karachi under the supervision of Interior Minister General Babar. It was a co-ordinated effort between elite security and intelligence agencies which used sophisticated monitoring equipment, network of informers, evaluation and corroboration of information acquired through interrogation and intelligence links within the MQM. ${ }^{43}$ In the process of the operation, the PPP government allegedly carried out extrajudicial killings, especially in fake police encounters, torture of the MQM's workers and persecution of the latter's families. The humiliating searches inside households and brutish behaviour of the police vis-à-vis the mohajir youth alienated the community still further. Not surprisingly, mohajirs continued to look towards the MQM for safeguarding their rights and interests. By the second quarter of 1996, the MQM's movement had been largely contained. While the MQM had intensely lobbied human rights organisations in and outside Pakistan, no generalised protest campaign against the government's strong-arm tactics against it emerged in the country. The MQM's failure lay in its inability to challenge the legitimacy of the elected PPP government at any stage from 1993-96 either at Karachi or in Islamabad.

\section{CONCLUSION}

It has been argued that the current scholarship on ethnicity is focused on the

\footnotetext{
${ }^{41}$ Reply Statement, op. cit., pp. 161-62.

${ }^{42}$ MQM: Constitutional Petition, Part 1, op. cit., pp. 52-86.

${ }^{43}$ Azhar Abbas, 'Future Shocks?', Herald, March 1996, p. $46 b$.
} 
rise of ethnonationalism, without incorporating the possibility and the nature of decline in its scope and intensity. ${ }^{44}$ An absolute majority of such movements have indeed been contained in the postwar era. It is unlikely that this trend will reserve in near future. In this context, one can point to the Pakhtun, Baloch and Sindhi nationalist movements in Pakistan which have been relatively contained within the framework of the political system of the country. One can hope that the mohajir nationalist movement will be reoriented towards a constitutional form of struggle and a parliamentary way to negotiating an ethnic bargain with other communities living in Sindh.

It is significant to note that it is the state at the non-policy level which created a situation of ethnic explosion in urban Sindh. Various macro-level issues revolving around conflicts between politicians and army, federalist and provincial forces, Islamist and secularist elements and, externally, India and Pakistan seriously circumscribed the state's capacity and will to pursue micro-level issues such as urban planning, educational and manpower strategies, as well as rural-urban and interprovincial migration. What is immediately required is the expansion of the servicegiving network of the state in order to incorporate large sections of the population. As the state defaulted on various counts such as citizen orientations, legal protection and security of life and property, ethnicity emerged as the new source of definition and categorisation of interests and identity formation. In other words, it was not too much of the (Jacobin) state, as primordialists would have us believe, but rather too little of it which produced the mohajir ethnic movement.

${ }^{44}$ Tahir Amin, op. cit., p. 256. 